\title{
MIĘDZY REDUKCJONIZMEM A POSZUKIWANIEM PEŁNI. POTRZEBA INTEGRALNEGO ROZUMIENIA CZLOWIEKA W DYSKUSJI ETYCZNEJ
}

We współczesnej humanistyce można zaobserwować poszukiwanie ujęć integralnych i integrujących ${ }^{1}$. Dzieje się tak pomimo faktu, że mamy do czynienia ze swoistym „zawłaszczaniem” przez nauki szczegółowe kwestii filozoficznych i odmawianiem prawa do ich podejmowania, w kontekście antropologicznym, poza obszarem tak zwanej „neuronauki” (ang. neuroscience). Badań naukowych nie należy oczywiście lekceważyć, jednak istnieje poważna obawa, że pośród gałęzi nikt już nie będzie dostrzegał drzewa, czyli całego człowieka. Jest to o tyle niebezpieczne, że wspomniane nauki szczegółowe, w osobach swoich przedstawicieli, bardzo chętnie przekraczają granice własnych kompetencji i wyprowadzają ze swych badań wnioski o charakterze filozoficznym czy nawet światopoglądowym.

Zanim zajmę się postulatem ujęć integralnych, podejmę próbę opisu świata współczesnego. Epokę „późnej nowoczesności”2 wydają się charakte-

${ }_{1}$ Por. np. A. Jastrzębski, W obronie integralności człowieka. Próba adekwatnego ujęcia filozofii psychologii, Warszawa 2011.

2 Pojęcie „późnej nowoczesności” ma charakter socjologiczny (Giddens, Delsol) i wydaje się dobrze charakteryzować epokę, w której wszystkie podstawowe cechy nowoczesności przybrały pewną graniczną postać. 
ryzować trzy aspekty: redukcjonizm w sferze myślenia o człowieku i świecie, technicyzacja oraz masowość. W kolejnych punktach zasygnalizuję konsekwencje powszechnego już redukcjonizmu, a także tendencje w sferze poszukiwań integralnej wizji człowieka.

\section{Redukcjonizm}

Redukcjonizm miał, oczywiście, różne przyczyny. Przede wszystkim uważano, że platonizujące chrześcijaństwo, wywodzące się głównie od św. Augustyna, zniekształca obraz człowieka. Była to słuszna konstatacja, jednak wydaje się, że wahadło poszukiwań przechyliło się w przeciwną stronę, ponieważ zaczęto kwestionować istnienie wewnętrznego, duchowego wymiaru człowieka.

Proces ten postępował krok po kroku co najmniej od czasów renesansu. W pewnym sensie redukcjonizm jest ułatwieniem sobie zadania przez wyjaśnianie całości określonego zjawiska za pomocą jakiejś grupy własności, które uznaje się za reprezentatywne. Sądzę jednak, że jest to błąd pars pro toto, którego skutki przekładają się na codzienne życie ludzi. Inna odmiana redukcjonizmu polega na wyjaśnianiu określonej grupy zjawisk przez inne zjawiska, do których sprowadza się te pierwsze. Podejście takie pozwala na dużą ilościową efektywność poznawczą, jednakże zapoznaje równocześnie aspekty, które mogą decydować o zupełnie innej drodze interpretacji. W niektórych ujęciach służy temu między innymi tworzenie "pojęć-wytrychów", które same w sobie zawierają już określoną interpretację zjawisk (np. pojęcie "superweniencji”) zgodną z obowiązującym status quo. Niektórzy badacze, których prace stosunkowo rzadko są rozpowszechniane w dużych nakładach, dostrzegają, np. w badaniach naukowych, silną preferencję do uprawiania nauki opartej na tak zwanym materializmie promisoryjnym $^{3}$. Materializm ten obiecuje, że jakkolwiek dzisiaj nie możemy rozwiązać wielu problemów, to w przyszłości na pewno to zrobimy, pozostając przy tych założeniach - mających często charakter metafizyczny - które dzisiaj przyjmujemy.

Redukcjonizm podlega procesowi, który można nazwać syndromem dziecka wylanego z kąpielą. Zapomina się o tym, że rzeczywistość (czymkolwiek by nie była) jest o wiele bogatsza niż aktualna wąska ścieżka poznawcza. I jeśli w zdobywaniu danych redukcjonizm jest na pewno skutecz-

${ }^{3}$ D. O'Leary, M. Beauregard, Duchowy mózg. Neuronaukowa argumentacja za istnieniem duszy, tłum. Z. Kasprzyk, Kraków 2011. Wcześniej mówił o takim podejściu np. John Eccles. 
ny, to cierpi często na amnezję. Amnezja ta, przyspieszając w wieku XX i dochodząc do swego kresu w wieku XXI, pozwoliła zepchnąć na margines zakłócające wiarę $\mathrm{w}$ postęp czynniki, takie jak np. poczucie straty czegoś cennego. Amnezja kultury Zachodu pogłębiała się w czasach powojennych, kiedy to lansowano nieokiełznany konsumpcjonizm. Wydatnej pomocy w tym zakresie użyczył scjentyzm, który w sposób nieuzasadniony rozszerza redukcjonizm metodologiczny. Jak pisze Marek Szulakiewicz: „Myślenie naukowe ma skłonność do wypierania innych reakcji i innych sposobów bycia. Jest ono myśleniem redukcjonistycznym" 4 . W badaniach naukowych podejście takie jest wręcz nieodzowne, jednak sami naukowcy dokonują często filozoficznych, metafizycznych uogólnień w sposób nieuprawniony. $\mathrm{Na}$ tego rodzaju postępowanie, świadczące o ideologizacji nauki, reagują niektórzy naukowcy ${ }^{5}$.

Redukcjonizm w życiu społecznym objawiał się jako, świadoma lub nie, alienacja. Na proces ten składa się wiele różnych zjawisk, których między innymi Karol Marks w swej tendencyjności zdawał się nie zauważać. I niestety, nie pomoże nic „przeniesienie”, o którym pisze Katarzyna Gurczyńska-Sady, w kierunku sfery społecznej, która miałaby być zaniedbana w przypadku starania się o osobistą doskonałość́ ${ }^{6}$. Autorka, powołując się na Hannę Arendt, twierdzi, że wystarczy zadbać o sferę zewnętrzną, publiczną, a wszystkim będzie dobrze. W XX wieku doszło do kilku prób wdrożenia podobnego redukcjonizmu w życie, zarówno w wersji wojennej, jak i pokojowej. Wiele tez redukcjonizmu weszło niejako do codziennego życia wspó1czesnych ludzi, dlatego daje się zauważyć proces poszukiwania rozwiązań bardziej integralnych jeśli chodzi o styl życia, wychowanie czy dbałość o dobro wspólne. Wspomniana Gurczyńska-Sady uważa, że wcześniejsze koncepcje podmiotu były naiwne, jednak propozycja dbania wyłącznie o sferę publiczną wydaje się dziedzictwem równie naiwnego behawioryzmu i socjologizmu7 ${ }^{7}$ Na nic się nie zda choćby najdoskonalsza organizacja i „zarządzanie zasobami ludzkimi", jeśli człowiek od wewnątrz, od strony swych postaw, nadziei i wartości, będzie spustoszony, pozbawiony sensu życia itd.

${ }^{4}$ M. Szulakiewicz, O człowieku w czasach trudnych, Torun 2012, s. 38. Oczywiście nikt nie kwestionuje nauki jako takiej, ale naukę, która ma charakter zideologizowany i nie służy już faktycznemu poszukiwaniu prawdy o rzeczywistości, ale interesom finansistów, polityków itp. Książki Marka Szulakiewicza są w moim przekonaniu najlepszym przykładem wnikliwych, bezstronnych poszukiwań $\mathrm{w}$ zakresie antyredukcjonistycznego rozumienia człowieka.

${ }^{5}$ Por. np. R. Sheldrake, Nauka - wyzwolenie z dogmatów, tłum. M. Majer, Wrocław 2015 Sheldrake twierdzi, że nauka podlega dziesięciu dogmatom o materialistycznym charakterze.

${ }^{6}$ K. Gurczyńska-Sady, Człowiek jako stowo i ciało, Kraków 2013, s. 216.

7 Wartościowanie określonych poglądów i ujęć jako naiwnych nie jest argumentem na rzecz uznawania ich za fałszywe. 
Podejście zaprezentowane w książce Gurczyńskiej-Sady jest przykładem redukcjonizmu, który nawet już nie reflektuje pytań o transcendencję i jej przyczyny $^{8}$. A należy dodać, iż nierozstrzygalność określonego problemu (czyli problemu istnienia Boga) nie jest powodem jego anihilacji i uznania, że wyłącznie np. stanowisko agnostyczne jest prawomocne. Czy jest to faktycznie nowa alternatywa, czy też rozwiązanie, którego już próbowano i przyniosło ono tylko zgubne efekty w praktyce? Sfery publicznej nie należy oczywiście lekceważyć, jednak sfera wewnętrzna wydaje się tą fundamentalną. Tak zwana sfera publiczna jest $\mathrm{w}$ dużej mierze zewnętrzną ekspresją sfery wewnętrznej, sfery przekonań, wartości, pragnień i dążeń9. W ślad za redukcjonizmem postępują różne formy manipulacji, stosowane zarówno w odniesieniu do sfery "prywatnej”, jak i publicznej. Oczywiście, redukcjonizm jest w pewnym sensie konieczny, jeśli pragnie się stworzyć coś, co Noam Chomsky nazwał „komfortową iluzją”. O prawdziwości tego stwierdzenia świadczyć może chociażby obszerna i wnikliwa praca Tadeusza Buksińskiego $^{10}$. Syndromów redukcjonizmu mamy bardzo wiele. Marek Szulakiewicz wskazuje np. na infantylizację kultury ${ }^{11}$. Owa infantylizacja dokonuje się dzięki umasowionej technice medialnej pozwalającej propagować treści odpowiednio spreparowane dla jak największej liczby odbiorców.

Jak widać na przykładzie mediów, znacznej pomocy redukcjonizmowi i społecznemu ubezwłasnowolnieniu udzieliła technika. Nie znaczy to oczywiście, że należy potępić sama technikę, jednak pozwala ona na redukcjonistyczne podejście, które manifestuje się też przez określony system wartości i styl życia. Bardzo praktycznym przykładem jest książka Marcina Po-

8 Por. recenzja O. Szmidt, Pstryczek w nos Kartezjusza, w: http://www.academia.edu/ 10090923/Pstryczek_w_nos_Kartezjusza_Katarzyna_Gurczy\%C5\%84ska-Sady_Cz\%C5\%

82owiek_jako_s\%C5\%82owo_i_cia\%C5\%82o._W_poszukiwaniu_nowej_koncepcji_podmiotu_ online_?login=wados77@interia.pl\&email_was_taken=true (dostęp 08.03.2015 r.).

${ }^{9}$ Nawet jeśli powiemy, że istnieje coś takiego jak „umysł społeczny”, to teza taka jest wyrazem dominującej metodologii, która pod pozorami niekwestionowalnego obiektywizmu bada człowieka jako czynnik społecznych interakcji (por. J.P. Forgas, K.D. Williams, L. Wheeler, Umyst społeczny. Poznawcze i motywacyjne aspekty zachowań interpersonalnych, tłum. A. Nowak, Sopot 2005). Wydaje się, że stopień przetwarzania danych w umysłach ludzkich pozwala, być w może $\mathrm{w}$ nielicznych przypadkach, na transcendencję zarówno społeczności lokalnej, jak i własnej kultury. W jaki sposób dochodziłoby w tej sytuacji do nowych odkryć i postępu w sztuce czy nauce? Czynna negacja wzorców kulturowych dowodzi również takiej możliwości.

10 Zob. T. Buksiński, Moderność, Poznań 2001.

${ }_{11}$ M. Szulakiewicz, op. cit., s. 30-31. Również samą filozofię systematycznie redukuje się w edukacji, a słowo „mądrość” pojmuje się również w sposób bardzo zawężony. Pośród osób zajmujących się filozofią niewielu jest takich, którzy rzeczywiście są miłośnikami mądrości, a nie np. wiedzy, do której owa mądrość została zredukowana. 
pkiewicza Świat na rozdrożu12, która jest wstrząsająca w swej wymowie. Sądzę, że sposób traktowania przyrody przez cywilizację Zachodu jest rezultatem określonej postawy kulturowej (która ma różne źródła), gdzie tak zwana natura uważana jest za przestrzeń do eksploatacji i wykorzystania. Konsekwencją redukcjonizmu, który eksponuje posiadanie, a nie bycie, jest właśnie sytuacja, jaką prezentuje nam książka Świat na rozdrożu.

\section{Technicyzacja}

Od chwili (raczej niezbyt łatwej do określenia), gdy ludzie stali się ludźmi, czyli od momentu antropogenezy, posługują się oni narzędziami. Równocześnie, w miarę intensyfikacji rozwoju technologicznego, napotykano na coraz większe opory środowiska i niejednokrotnie destruktywne oddziaływanie techniki na człowieka, o czym pisano już wiele (np. M. Heidegger, J. Ellul, N. Postman, H. Skolimowski i in.) ${ }^{13}$. Faktem jest, iż „niezależnie jak zdefiniujemy człowieczeństwo, przestaniemy być ludźmi, jeśli zaprzestaniemy twórczości technicznej"14. Jest to absolutnie słuszne, jednak technikę można podzielić na taką, która jest tylko "przedłużeniem ręki”, oraz taką, która jest "przedłużeniem głowy”, przez co zaczyna dominować nad człowiekiem, manipulować nim i uzależniać go od techniki rozumianej systemowo ${ }^{15}$.

Mamy więc do czynienia z procesem, który niektórych zachwyca (np. transhumaniści), a innych przeraża (np. Theodore „Ted” Kaczynski), w coraz większym stopniu oddziałując na społeczeństwo, co może skłaniać do teorii determinizmu technologicznego. Siła techniki polega na tym, że sprzęgła się ona z nauką, tworząc technonaukę, która w żadnym wypadku nie jest neutralna ${ }^{16}$. Dlatego też, sądzę, że drugą (obok redukcjonizmu) właściwością epoki „ponowoczesnej” jest technizacja. Technicyzacja uzyskuje

12 M. Popkiewicz, Świat na rozdrożu, Katowice 2012.

${ }^{13}$ Pomijam w tej chwili omówienie samej filozofii techniki, która rozwija się bardzo intensywnie. Technika jako fenomen ludzki stanowi obszar bardzo istotnych poszukiwań antropologicznych. W tym paragrafie chcę się skoncentrować na samej technicyzacji w jej kontekście użytkowo-konsumpcyjnym.

14 A.P. Wierzbicki, Technika a zmiana episteme. Skutki rewolucji informacyjnej w pojmowaniu świata, [w:] Nauka - Technika - Społeczeństwo. Podejścia i koncepcje metodologiczne, wyzwania innowacyjne i ewaluacyjne, red. L.W. Zacher, Warszawa 2012, s. 149-189.

15 V. Dusek, Wprowadzenie do filozofii techniki, tłum. Z. Kasprzyk, Kraków 2011, s. 41. Technika ujmowana systemowo rozumiana jest jako czynnik współistnienia z działaniami ludzki$\mathrm{mi}, \mathrm{z}$ wiedzą człowieka na jej temat, używaniem technicznej infrastruktury zgodnie z jej przeznaczeniem i w sposób uwarunkowany tą wiedzą.

16 Por. E. Bińczyk, Technonauka w społeczeństwie ryzyka, Torun 2013, s. 22. 
aktualnie charakter powszechny. Przeniknęła do niemal każdego aspektu życia większości społeczeństw w krajach rozwiniętych i rozwijających się.

Tempo technicyzacji życia nasila się, co spowodowane jest wzrostem roli i znaczenia badań naukowych, a także skalą produkcji i dystrybucji wytworów technicznych. Cały paradygmat naukowo-techniczny, sprzęgnięty z możliwością wytwarzania, wychodzi z redukcjonistycznych założeń, które tak wnikliwie opisał Martin Heidegger w swoim słynnym eseju17. Rodzi to określone konsekwencje.

Zdecydowana większość przedsięwzięć człowieka, zarówno w sferze prywatnej, jak i publicznej, powiązana została z techniką ${ }^{18}$. Technika współczesna wprowadza czynnik "panowania” nad przyrodą w stopniu do tej pory niespotykanym, który równocześnie kreuje złudzenia, a największym z nich jest przekonanie o ludzkiej niezależności od przyrody oraz o jej niewyczerpywalnych zasobach, które mają stanowić źródło nieograniczonego zaspokajania potrzeb ${ }^{19}$. Technicyzacja staje się technokracją, ta zaś z kolei, jako ze-staw, pozwala wszystkim "zarządzać”, od maszyny po człowieka ${ }^{20}$. Głównym zadaniem ludzi w cywilizacji technokratycznej jest znajomość procedur postępowania $\mathrm{w}$ związku $\mathrm{z}$ powszechnym zastosowaniem technologii. Specjaliści, przejmujący wiodące funkcje w takim społeczeństwie, często w ogóle nie zdają sobie sprawy z ryzyka aktualnego i przyszłego ${ }^{21}$. Natomiast ci, którzy nie nauczą się procedur postępowania, mogą zostać wykluczeni ze społecznego systemu, co czasem czynią dobrowolnie (np. wspomniany Kaczynski) ${ }^{22}$. Jest to o tyle nieuniknione, że myślenie technokratyczne (w szerokim sensie tego słowa) generuje postawę, która twierdzi, że nie jest preferencją określonych wartości. Tak jednak się nie dzieje. „Miernikiem wartości w myśleniu technicznym jest tylko użyteczność"23. Użyteczność natomiast nie jest sferą, która może napełnić sensem i trwałym szczęściem życie człowieka. Może ona pewne rzeczy usprawnić, ale nie rozwiązuje kwestii du-

${ }_{17}$ M. Heidegger, Pytanie o technikę, [w:] idem, Budować, mieszkać, myśleć. Eseje wybrane, tłum. K. Michalski [et al.], Warszawa 1977.

${ }^{18}$ L.W. Zacher, Relacja technika - społeczeństwo jako przedmiot badań i ewaluacji. Przeglad problematyki, [w:] Nauka - Technika - Społeczeństwo, op. cit., s. 15 i n.

${ }^{19} \mathrm{~J}$. Łukasiewicz, Eksplozja ignorancji. Czy rozumiemy cywilizacje przemystowa?, tłum. A. Rabś-Retkiewicz, Warszawa 2000. Autor bardzo wnikliwie analizuje różne aspekty problematyki człowieka w cywilizacji naukowo-technicznej.

${ }^{20}$ V. Dusek, op. cit., s. 60.

${ }^{21}$ E. Bińczyk, op. cit., s. 330.

22 Oprócz narastającego problemu bezdomności czy migracji, na marginesach współczesnych społeczeństw Zachodu rozwija się coraz więcej alternatywnych społeczności, które podejmują się przedsięwzięć mających na celu wypracowanie innego niż "obowiązujący" stylu życia.

${ }^{23}$ M. Szulakiewicz, op. cit., s. 38. 
chowych i egzystencjalnych. Kwestie te są po prostu pomijane, aczkolwiek nie da się od nich uciec na dłuższą metę, prowadząc egzystencję skoncentrowaną np. na pieniądzu lub karierze zawodowej.

Czy faktycznie miał rację Neil Postman, że po technokracjach przyjdą technopole?24 Niektóre przewidywania obu przed chwila wymienionych autorów jak najbardziej się sprawdzają. Technicyzacja obejmuje coraz więcej dziedzin, natomiast dziedziny "miękkie”, jak np. filozofia czy sztuka, są marginalizowane, a nawet całkowicie eliminowane jako zupełnie nieprzystające do sytemu, w którym dominuje behawioryzm i wszechwładna specjalizacja. Tymczasem to właśnie sztuka i filozofia (rozumiana również jako określony styl życia), jako istotne elementy kultury, pozwalają budować naszą „przestrzeń człowieczeństwa”.

Technicyzacja narzuca określony - płytki i redukcjonistyczny - sposób myślenia, depersonalizując człowieka, sprowadzając go do roli bezwolnego funkcjonariusza ${ }^{25}$. Następnym krokiem może być zupełna eliminacja "czynnika ludzkiego". Człowiek w "świecie techno" jest o wiele głębiej wyalienowany niż robotnik w XIX wieku. Jest on niekiedy wyalienowany ze społeczeństwa, z przyrody, wreszcie z własnego człowieczeństwa. Umożliwia to uwolnienie nie zawsze dobrych stron ludzkiej natury. Powracają plemienne i ksenofobiczne formy zachowań. Inaczej mówiąc, frustracja współczesnego człowieka (uwidaczniająca się na różne sposoby) jest swoistym dowodem na fakt, iż nie jest możliwe spełnienie w horyzontalnym wymiarze egzystencji, że poszukiwanie szczęścia musi uwzględniać wszystkie perspektywy, ażeby w ogóle stworzyć warunki do jego odczuwania przez osobę w pełni dojrzałą. Jest to być może jedna z przyczyn popularności psychologii integralnej w wersji stworzonej przez Kena Wilbera, do której jeszcze wrócę.

Zasadnicze pytanie, jakie się rodzi, to kwestia, czy technopol może „rozwijać” się, degradując człowieka, bez końca? Nawet jeśli nadal będzie się wdrażać redukcjonistyczne założenia, nie wydaje się to możliwe ${ }^{26}$, bo-

${ }^{24}$ N. Postman, Technopol. Jak technika niszczy kulturę, tłum A. Tanalska-Dulęba, Warszawa 2004; zob. szczególnie rozdział III. Anegdotycznie można wspomnieć, że na Politechnice Wrocławskiej powstał budynek nazwany „Technopolis”. Otrzymanie pozwolenia na przeprowadzenie wyznaczonych zajęć $w$ tym budynku graniczy z cudem, natomiast sale wykładowe są wyposażone $\mathrm{w}$ najnowocześniejszy sprzęt i automatykę, jednak brakuje zwykłej instrukcji, która informowałaby o sposobie ich użytkowania.

${ }^{25}$ Por. np. J. Kępińska, Technologia kultury, „Dzikie Życie” 1977, nr 6/37.

26 Redukcjonizm siłą rzeczy omija pewne aspekty rzeczywistości, dlatego prędzej czy później dochodzi do sytuacji zaburzającej jego funkcjonowanie, a nawet kończącej jego tryumfalny pochód. Na przykład zredukowanie sposobu odżywiania się do jednego rodzaju pokarmu z dużym prawdopodobieństwem będzie prowadzić do chorób, a nawet śmierci. W dłuższym wywodzie można uzasadnić taką tezę. Chodzi przede wszystkim o fakt pomijania przez redukcjonizm pewnych istotnych, często niezauważanych i niedocenianych aspektów rzeczy- 
wiem nie jest on w stanie przynieść człowiekowi poczucia harmonii czy spełnienia. Nie jest to możliwe $z$ tego powodu, że sfera ludzkiego wnętrza ma charakter holistyczny i prędzej czy później doprowadzi go do świadomości, iż nie może on $\mathrm{w}$ nieskończoność postępować na ścieżce autodestrukcji oraz dewastacji swego otoczenia ${ }^{27}$.

Istnieją, oczywiście, poważne argumenty na rzecz pozytywnego charakteru techniki przy odpowiednim, racjonalnym $\mathrm{z}$ niej korzystaniu. Inaczej mówiąc - nie można demonizować techniki. Ponadto, sama technika powinna w coraz większym stopniu nabierać aspektu humanizującego. Niewątpliwie, dokonuje się aktualnie koewolucja świata ludzkiego i świata komputerów sprzężonych $\mathrm{w}$ sieci globalnejej. W dużej mierze od samych użytkowników zależy, w jakim kierunku owo sprzężenie się rozwinie. Równocześnie sam człowiek owija się w kokon technologii, tworząc rzeczywistość własnych doświadczeń w świecie elektronicznej antroposfery ${ }^{29}$. Optymizm Michała Ostrowickiego i jego przekonanie o wyższości świata wirtualnego (np. w edukacji) wydaje się lekko przesadny, jeśli zwrócić uwagę na fakt, że cały ów świat uzależniony jest w swym istnieniu od funkcjonowania cywilizacji produkującej energię, komputery itd. Problemy gospodarcze, konflikt wojenny czy eskalacja problemów społecznych mogą uniemożliwić dalszy rozwój w tym kierunku. Bezmyślny zachwyt nad techniką i wiara, że najnowsze technologie są w stanie rozwiązać wszystkie problemy, jest kolejną iluzją. Wielorakie udogodnienia techniczne służą często złagodzeniu narastających problemów i trudności o znacznie poważniejszym wymiarze niż szybkie ugotowanie obiadu. Ponadto, nie należy zapominać o silnym uzależnieniu od techniki, które prowadzi do swoistego ubezwłasnowolnienia i bezradności w sytuacji, gdy jej zabraknie.

Nie chodzi o to, aby potępiać technikę, ale aby nie pozwolić na zubożenie ludzkiego życia, a zamiast tego odkrywać jego walory w bezpośrednim kontakcie z przyrodą i z drugim człowiekiem. Technika może być tylko instrumentem podtrzymywania i poprawiania niektórych aspektów ludzkiego życia, nie wydaje się jednak możliwe, aby mogła je w pełni organizować i zagwarantować ludziom jakiś rodzaj szczęścia, chyba że odwołamy prawo

wistości, co w określonym rytmie czasowym skutkuje poważnymi, w tym również śmiertelnymi dla cywilizacji, tendencjami. Por. np. A.L. Zachariasz, Człowiek wobec pytania o sens istnienia. Wprowadzenie do antropologii anatelicznej, Lublin 1996, szczególnie rozdziały VIII i IX, oraz: M. Szulakiewicz, Poszukiwania metafizyczne, Torun 2014, szczególnie rozdział I.

27 Świadczą o tym różnorodne „oddolne” ruchy społeczne (np. freeganie), które pozwalają mieć nadzieję na powrót do wspólnot, które faktycznie będą tworzyć zrównoważony rozwój.

${ }^{28} \mathrm{~J}$. Garreau, Radykalna ewolucja. Czy człowiek udoskonalony przez technikę będzie jeszcze cztowiekiem?, tłum. A. Kloch, A. Michalski, Warszawa 2007.

${ }^{29}$ S. Myoo (M. Ostrowicki), Ontoelektronika, Kraków 2013, s. 50 i n. 
do autonomii i wolności. To właśnie zresztą próbuje się czynić, wprowadzając nowe ideologie technokratyczne i systemy wartościowania społecznego oparte na posiadaniu, bądź nie, określonych artefaktów technicznych (samochodów, smartfonów itd.) czy kompetencji związanych z „zarządzaniem" technologiami. Należy mieć nadzieję, że postulat integralnego rozumienia człowieka w jego aspekcie indywidualnym i społecznym będzie uzyskiwał coraz większe poparcie szerokich grup społecznych odczuwających w swoim doświadczeniu bolesne konsekwencje redukcjonizmu.

\section{Masowość}

Redukcjonizm i technicyzacja prowadzą do rozwoju społeczeństwa masowego i są ściśle sprzężone z jego powstaniem. Masowość jest syndromem coraz większej ilości działań ludzkich. Społeczeństwo masowe było już opisywane wielokrotnie (np. przez Herberta Marcusego, Ericha Fromma i in.), dlatego skoncentruję się na aspekcie, który w dużym stopniu zmienia charakterystykę takiego społeczeństwa. Chodzi o elektroniczną antroposferę, która - jako określona wypadkowa ludzkich działan - pozwala na implementację wartości decydujących o ludzkiej rzeczywistości30. Michał Ostrowicki twierdzi, że człowiek niejako "zawija” się w technologię jak w kokon, który nieustannie ewoluuje ${ }^{31}$. Sieci informacyjne, szczególnie Internet, stają się niemal wszechobecne, w coraz większym stopniu wpływając na relacje i zachowania ludzkie ${ }^{32}$. Sieć staje się przestrzenią jeszcze bardziej masowego, zamaskowanego i anonimowego funkcjonowania, zwykle w sferze wartości, które mają niemal wyłącznie wirtualny żywot. Są to więc symulakry wartości. Właściwie media elektroniczne sprzyjają masowości, nie tylko przez anonimowość. Coraz więcej przedsięwzięć społecznych przenoszonych jest do sfery technologii wirtualnych: edukacja, administracja, praca, finanse itd. Funkcjonując w systemie życia społecznego, jednost$\mathrm{ka}$, chcąc nie chcąc, musi podlegać nieustannie procesom akomodacji33. Pomijając najprostsze prace (wykonywane coraz częściej przez roboty), każdy uczestnik życia społecznego musi znaleźć się w przestrzeni masowej i transparentnej. Masowe zachowania, żerując między innymi na potrzebie przy-

\footnotetext{
${ }^{30}$ Zob. ibidem, s. 50.

31 Ibidem, s. 51. Kontynuując tę metaforę Ostrowickiego, można zapytać, czy technologia posłuży człowiekowi do tego, aby rozwinął się w pięknego motyla i opuścił kokon?

32 Zob. S. Turkle, Samotni razem. Dlaczego oczekujemy więcej od zdobyczy techniki, a mniej od siebie nawzajem, tłum. M. Cierpisz, Kraków 2013, s. 39.

33 S. Myoo, (M. Ostrowicki), op. cit., s. 52.
} 
należności, wymuszają niejako określone standardy myślenia i wartościowania, co gorliwie wspierane jest przez biznes, zarabiający na masowych modach i trendach.

Masowość oznacza standaryzację, wytworzenie modeli (człowieka, życia, pracy itd.) obowiązujących niemal nieustannie. Tworzy ona określone wzorce o charakterze public correct. Masowość tego rodzaju absolutyzuje „postęp", któremu służy uprzedmiotowienie samego człowieka. Ten zresztą chętnie do tego dąży, ponieważ chce - jak przypuszcza - maksymalnie ułatwić swoje życie i dowieść swojej wartości przez zewnętrzny "sukces” 34 . Kultura masowa homogenizuje wszystkie wartości, skutecznie utrzymując masowego konsumenta $\mathrm{w}$ letargu, co pozwala w jeszcze większym stopniu nim manipulować, tworząc iluzje wolności.

Omówione przed chwilą zjawiska nie wyczerpują, oczywiście, listy różnorodnych syndromów regresu cywilizacyjnego. Można by wskazać ich znacznie więcej. Wydaje się, że skutkują one jednak w różnych obszarach negatywnymi procesami.

\section{Konsekwencje redukcjonizmu}

Sądzę, że najpoważniejszym błędem "późnej nowoczesności” jest omówiony wcześniej redukcjonizm połączony z ideologizacją i fetyszyzacją jednego z aspektów życia człowieka. Zasadniczo chodzi tu o aspekt materialno-behawioralny. Redukcjonizm jest potrzebny, aby skutecznie manipulować człowiekiem na skalę masową. Natomiast problem dobra i zła rozpatruje się głównie poprzez metodologię empiryczno-obserwacyjną (np. F. Zimbardo, S. Baron-Cohen i in. $)^{35}$. Ponieważ nie tylko „ponowoczesność” stała się „płynna”, również człowiek zaczął, co najmniej od czasów Fryderyka Nietzschego, zatracać jakąkolwiek tożsamość i „właściwości” (Robert Musil). Proces, zainicjowany w kulturze Zachodu już dość dawno, prowadzi do sytuacji, kiedy to "relatywizacja tego, «co ważne», jest tożsama $\mathrm{z}$ jego zniknięciem" 36 . W tym momencie powstaje syndrom „domu bez fundamentów". Różnorako możemy uzasadniać dobro. Wydaje się jednak, że doszło,

\footnotetext{
${ }^{34}$ J. Łukasiewicz, op. cit., s. 1 i n. Krótki, ale wnikliwy rozdział Łukasiewicza na temat postępu został, jak sądzę, potwierdzony przez późniejszych badaczy (w Polsce np. E. Bińczyk, R. Lizut, T. Buksiński, A. Kiepas i in.)

${ }^{35}$ Nie umniejszam, oczywiście, ogromnych zasług wspomnianych badaczy, których prace są bardzo cenne i odkrywcze, jednak chodzi o to, że badania te nie wyczerpują pola eksplanacyjnego problemu dobra i zła.

36 J. Łukasiewicz, op. cit., s. 81.
} 
z jednej strony, do subiektywizacji kategorii dobra, z drugiej strony - do zredukowania pytania o zło i dobro wyłącznie do kwestii osobistych lub behawioralnych. Zjawisko to można określić mianem subiektywistycznego behawioryzmu, co brzmi na pierwszy rzut oka paradoksalnie, ale dobrze oddaje siłę propagandy iluzorycznego, wyalienowanego i egoistycznego stylu życia. Powstaje tutaj pytanie, czy nie miał racji np. Feliks Koneczny (nieco zapomniany w Polsce), który wskazywał na konieczność utrzymania równowagi między pięciomianem cywilizacyjnego bytu ${ }^{37}$

Wszyscy oczywiście zgodzą się z tym, że człowiek jest unikalną istotą, w związku z czym posiada unikalne doznania. Odczucia moralne należą do naszych qualiów, które mają charakter subiektywnych wrażeń. W tym sensie pewne twierdzenia zawsze możemy uznać za subiektywne. Idea subiektywizmu (silniejsza u Stirnera, Nietzschego czy Sartre'a) w kwestii dobra i zła zakłada, iż jako ludzie jesteśmy ontologicznie wręcz zamknięci w sferze własnych, indywidualnych doznań. W subiektywistycznych dążeniach tkwi pragnienie niczym nieograniczonej wolności. Podejście subiektywistyczne buduje swoje argumenty nie tylko na fakcie osobistych upodobań, ale też na przekonaniu, iż ocena jakiegoś działania jako dobrego lub złego wynika z określonej relacji danej osoby do przedmiotu oceniania. Subiektywizm jest intelektualnie wygodny, ponieważ tworzy własne kryteria, które również może stosować w sposób niekonsekwentny, zmieniając je w zależności od kontekstu ${ }^{38}$.

Paradoksalnie, z subiektywizmem harmonizuje behawioryzm, wdrażany współcześnie przez masową kulturę. Na przykład Gurczyńska-Sady kontynuuje to podejście, prezentując obraz człowieka bez wnętrza, który nigdy nie myśli samodzielnie, nie jest twórczy, będąc tylko cieniem społeczności jako „my”39. Autorka ogłasza swoistą „śmierć człowieka”, który jest zlepkiem "my” i nicości ${ }^{40}$. Można tu zadać pytanie, jak doszło do powstania owego bezosobowego "my”, które ma wypełniać każdego? Jak rozumieć, oczywistą wręcz, transcendencję człowieka w różnorodnych jego wymiarach twórczości: wdrażania różnych wartości czy zdolności do negacji utartych

\footnotetext{
37 Chodzi o takie wartości, jak: Dobro, Piękno, Prawda, Zdrowie i Dobrobyt. Zob. F. Koneczny, O wielości cywilizacji, Kraków 1935, s. 134. Być może Koneczny ma rację, twierdząc, że określone prawa dziejowe ( $\mathrm{w}$ tym przypadku prawo syntez) uniemożliwiają łączenie cywilizacji w taki sposób, aby efekt był konstruktywny. Nie można na przykład traktować kobiet równocześnie instrumentalnie i podmiotowo.

${ }^{38}$ Oczywiście, wspomniane qualia są osobnym, niezwykłym fenomenem, który nieustannie wymyka się nauce. Doświadczenie własnego wnętrza, np. doświadczenie wartości, nie oznacza subiektywizmu głoszonego jako określony pogląd.

${ }^{39}$ K. Gurczyńska-Sady, op. cit., s. 222.

${ }^{40}$ Ibidem, s. 224.
} 
obyczajów? Kto jest tutaj podmiotem działań zmieniających niekiedy bieg historii? Wynalazki, dzieła sztuki itp. powstawały w wyniku twórczego geniuszu jednostek. Jakkolwiek język, który eksponuje Gurczyńska-Sady, jest „żywiołem” wytworzonym „pomiędzy” ludźmi (choć należy przypuszczać, że zaczął się rodzić między dwoma osobnikami, nie zaś w przekrzykującym się stadzie), to w wydaniu jednej osoby może stać się elementem niezwykle twórczym, podobnie jak kolory w malarstwie czy dźwięki w muzyce. Ta różnorodność środków wyrazu świadczy choćby o fakcie, że człowiek zdecydowanie wyrasta ponad język, aczkolwiek wiele osób pozostaje w swojej ekspresji w jego obrębie. Należałoby powiedzieć odwrotnie - sfera publiczna jest wtórna wobec spotkania, powstaje jako skutek pobudzenia osób do bycia "trans-podmiotami".

Propagowanie przez edukację, media, prasę itp. zawężonej wizji człowieka i społeczeństwa skutkuje ogromną ilością nieporozumień, cierpień, iluzji, nieszczęść i tragedii ludzkich, zniszczenia środowiska itp. Zachłanność i postawa roszczeniowa, prezentowana często przez młodzież, nie powstały wewnątrz klasycznej rodziny, ale na skutek uporczywego reklamowania takiego stosunku do świata. Propaganda taka przyczynia się również do pogłębiania kryzysu całej cywilizacji1" ${ }^{41}$ Musil nie przewidywał takiej sytuacji, ubolewając tylko nad faktem zaszufladkowania człowieka we „właściwościach”. Należy przypuszczać, że dzieje zweryfikują każdą skrajność oraz jednostronność, na którą redukcjonistyczne wychowanie skazuje społeczeństwa. Należy jednak przynajmniej wspomnieć, że zanim do tego dojdzie, będzie wiele ofiar cywilizacji, która zignorowała holistyczną naturę człowieka.

Zauważyć można również narastającą świadomość tak zwanego „błędu antropologicznego", obecną pośród coraz szerszej grupy uczonych, nie zawsze akceptowanych przez swoich kolegów. Przykładem takiego badacza jest Mario Beauregard, którego książka Duchowy mózg jest nie tylko raportem $\mathrm{z}$ rozległych badań, jakie prowadzi ten uczony, ale zawiera również bardzo dużo uwag na temat wspomnianego już "materializmu promisoryjnego", który wychodzi z redukcjonistycznych założeń ${ }^{42}$. Przeciwko redukcjoni-

41 Por. P.J. Buchanan, Śmierć Zachodu. Jak wymierające populacje i inwazje imigrantów zagrażaja naszemu krajowi i naszej cywilizacji, Wrocław 2005. Książka Buchanana odnosi się przede wszystkim do USA, jednak niektóre analizy mogą być jak najbardziej zastosowane do procesów zachodzących na starym kontynencie. Diagnoza tego autora jest być może nieco radykalna, jednak dzięki temu może dać do myślenia.

42 D. O'Leary, M. Beauregard,. op. cit. Pracą o podobnym wydźwięku, napisaną przez lekarza kardiologa, jest pozycja P. van Lommela, Wieczna świadomość. Naukowa wizja "Życia po $\dot{z} y c i u "$, tłum. M. Woźniak-Diederen, Warszawa 2010. To tylko przykładowe prace prezentują- 
zmowi w nauce występuje już grupa uczonych, której manifest można znaleźć w Internecie ${ }^{43}$. Jeśli faktycznie nauka ma być dostarczycielem wiarygodnych przekonań, post-materializm nie powinien być przemilczany.

Wydaje się więc, że społeczności różnych regionów świata mogą dziś odkryć wspólne wartości, mimo kulturowych podziałów. Sądzę, że wartości odkrywane są $\mathrm{w}$ dialogu i relacji, niekiedy w konstruktywnym sporze i dystansie, który - w swym wymiarze duchowym - może być doskonalszą formą wspólnoty niż największe zbliżenie z innymi. Jest to, niejednokrotnie "oddolny", proces przywracania człowiekowi jego godności przez wyzwolenie od nienawiści, potrzeby zemsty na "obcych" itd. Przykład takiego działania dali nam Jan Paweł II czy Dalajlama. Dokonuje się to również w relacji z Absolutem, który, w kontekście biblijnym, okazuje się zupełnie kimś innym niż ten obecny w dość abstrakcyjnym jego rozumieniu w powierzchownej mentalności europejskiej. W tym kontekście można zauważyć, że integralne ujęcie człowieka związane jest z koniecznością zerwania z nawykiem kartezjańskiego, abstrakcyjnego często rozumienia osoby (nie podmiotu!). Nawet samo pojęcie osoby jest tu zbyt wąskie, ponieważ istota ludzka odnajduje się w relacjach z innymi, z przyrodą czy Absolutem, i odkrywa potrzebę "troski o siebie" (gr. epimelea heautou), później przekształconej w zasadę gnothi seauton ${ }^{44}$. Podejście takie, niewątpliwie obecne $\mathrm{w}$ filozofii, ciągle zatrzymywało się albo na krytyce poprzednich ujęć, albo też na wyeksponowaniu jakiegoś aspektu, który akurat wcześniej był ignorowany. Człowiek jednak wykracza poza to, co empiryczne, i wkracza w sferę tego, co metafizyczne ${ }^{45}$. Owa „metafizyczność” może objawiać się na różne sposoby, jej wyparcie natomiast manifestuje się poprzez różnego rodzaju patologie i nadużycia. Jeśli przyroda rządzona jest określonymi prawami, które dają jej możliwość istnienia i ewolucji, to tym bardziej człowiek, który podlega również prawom ducha ${ }^{46}$.

Dobro i zło podlegają różnicowaniu, jednak nie na sposób relatywistyczny, ale w kontekście wcześniejszego pytania o zasadność takiej, a nie innej wizji człowieka. Wizja taka zostaje przyjęta uprzednio, dlatego implikuje

ce, jak sądzę, wiarygodne argumenty za inną wizją rzeczywistości niż ta, którą proponuje „twarda" nauka.

${ }^{43} \mathrm{http}$ // / opensciences.org/about/manifesto-for-a-post-materialist-science (dostęp: 13.09.2015 r.).

${ }^{44}$ M. Foucault, Hermeneutyka podmiotu, tłum. M. Herer, Warszawa 2012, s. 28.

${ }_{45}$ M. Szulakiewicz, op. cit., s.33. Powstaje tutaj pytanie, jak rozumieć ów metafizyczny wymiar, co Szulakiewicz prezentuje we wspomnianej wcześniej książce Poszukiwania metafizyczne (por. przypis 11). Zob. też: Cz. Piecuch, Człowiek metafizyczny, Warszawa - Kraków 2001.

${ }^{46}$ Por. F. Koneczny, Prawa przyrody i ducha, Krzeszowice 2004, s. 21. Koneczny wyjaśnia dość prosto różnicę między prawami przyrody a prawami ducha. 
ona rozumienie obszaru wartości i antywartości. Wynika to z logicznej i metafizycznej przesłanki o konieczności utożsamienia bytu z dobrem ${ }^{47}$. Nie wydaje się również, aby zawsze i w każdym przypadku można było jasno i do końca określić dobro i zło ${ }^{48}$. Można natomiast postawić hipotezę, iż im bardziej człowiek jest ugruntowany w tym, co uznaje (jako istota integralna) za dobro, tym bardziej istnieje jako świadomość ludzka. Można też, na bazie rozmaitych doświadczeń różnych narodów, określić dokładnie, co jest faktycznie destrukcją i zniszczeniem dla człowieka w określonej kulturze, a co wspomaga jego rozwój i inklinację do dobra, którą wszyscy zdają się posiadać.

Zło i dobro przeplatają się nadal w doświadczeniu. Niekiedy, jak perswadował Mefistofeles w Fauście Goethego, dobro powstaje tam, gdzie szczególnie panoszyło się wcześniej zło, co widać na podstawie żywotów wielu świętych ${ }^{49}$. I odwrotnie, złudzenie, iż jest się człowiekiem dobrym, bez cienia jakiejkolwiek skazy, może prowadzić do duchowej ślepoty w kontekście ewidentnego zła ${ }^{50}$. Jeśli uznamy, że dobro jest budowaniem, a zło niszczeniem (w różnych wymiarach egzystencji), to możemy zauważyć, że zło pojawia się wszędzie tam, gdzie człowiek uznaje najwyższą wartość tego, co relatywne, zapominając to, co relacyjne i tworzące „substancję" wspólistnienia, które jest nam dane jako pierwotne. Tak więc, jeśli organizacja, technika, pieniądz czy jakakolwiek inna wartość instrumentalna zaczną dominować nad wartościami autotelicznymi, w tym momencie prędzej czy później pojawi się destrukcja, kryzys itd. Okazuje się bowiem, że ważna jest sama realizacja wartości instrumentalnych, natomiast ich funkcje i celowość okazują się $\mathrm{w}$ praktyce bez znaczenia ${ }^{51}$.

Jeśli natomiast chociaż na moment zdystansujemy się od naszych „żywotnych" interesów, okaże się, że możemy się zbliżyć do bram mądrości i dostrzec, iż nawet śmierć nie musi być największym złem. Krzywda, którą nam zadano, może pomóc ogołocić się z iluzji pochlebiania sobie, że coś się wie lub potrafi. Zadane cierpienie może pozwolić przekuć je $\mathrm{w}$ pozornie

${ }^{47}$ A. Niemczyk, Traktat o złu, Lublin 2013, s. 180.

${ }_{48}$ Poszukiwanie pełnej jasności i pewności jest jednym z elementów pokartezjańskiego dziedzictwa

${ }^{49}$ Warunkiem takiej metamorfozy jest, oczywiście, uznanie takich pojęć jak prawda i zło, czyli po prostu nazwanie swego działania w perspektywie określonej deontologii.

50 Jest to tajemnica samozakłamania (zarówno wymiarze indywidualnym, jak i społecznym), które może zajść bardzo daleko. Doskonale ilustruje to bajka Hansa Christiana Andersena Nowe szaty króla. W sferze wspomnianego wcześniej public correct daje się zauważyć wyraźnie przejawy „syndromu nagiego króla”.

51 Por. M. Golka, Cywilizacja wspótczesna i globalne problemy, Warszawa 2012, s. 213. Marian Golka dotyka tutaj jednej z najbardziej kluczowych kwestii współczesnego świata. 
bezsilne odpłacanie dobrem za to, co uznano za zło, a co zostało uczynione z powodu lęku, namiętności, żądzy itp. Zło pochodzi z niedoskonałości człowieka oraz jego złożoności - banalność takiej tezy ukazuje z kolei fakt, iż jakakolwiek forma redukcjonizmu może okazać się źródłem systemów zła zorganizowanego, blokujących rozwój zarówno w wymiarze horyzontalnym, jak i wertykalnym. Istnieją oczywiście rzadkie jednostki, które mają na tyle męstwa, aby przeciwstawić się różnorodnym formom ograniczenia czy manipulacji. Bardzo możliwe jednak, że wielu jest dobrymi tylko dlatego, że obawiają się określonych społecznych konsekwencji swojego działania.

Istota w pełni rozwinięta, pełna wewnętrznego pokoju i radości, nie jest zainteresowana jakimkolwiek złem, niezależnie od światopoglądu czy kultury. Inaczej mówiąc, jeśli przyjmiemy, że naturalnym dążeniem człowieka jest, świadoma lub nie, inklinacja do tego, co człowiek uznaje za wartość konstruktywną, to niezależnie od historycznego i geograficznego usytuowania, człowiek ten będzie dążył do dobra, które będzie miało charakter interpersonalny - zatem przekonanie, iż dobro to "przedmiot" godny ludzkiej energii i czasu, będzie udziałem większości. Na każdej drodze człowiek, świadomie lub nieświadomie, poszukuje pełni.

\section{Poszukiwanie pełni ${ }^{52}$}

W czasach dominacji specjalizacji, gdy każdy uczony zamknięty jest $\mathrm{w}$ obszarze własnych badań, mówienie o podejściu integralnym wydaje się pretensjonalne. Przyjrzyjmy się jednak dyskusjom (vide np. IX Zjazd Filozoficzny w Wiśle, szczególnie panele dyskusyjne), jakie prowadzą ze sobą filozofowie. Większość z nich jest sporami „obok”, wyrazem niezdolności słuchania innego, zestawem zwerbalizowanych uprzedzeń związanych z wyznawaniem określonej opcji światopoglądowej czy politycznej. Tymczasem wydaje się, że stan cywilizacji (a także planety) pogarsza się, staje się destrukcyjny zarówno dla przyrody, jak i dla człowieka, i „okopywanie" się w sferze światopoglądów, ideologii i wzajemnych niechęci jest syndromem braku świadomości, jak poważna jest sytuacja współczesnego świata ${ }^{53}$. Jakie

52 Por. B. Kmiecik, Dążenie do petni człowieczeństwa. Studium teologicznomoralne w oparciu o pisma Edyty Stein, (nieopublikowana rozprawa doktorska), Opole 2014. Por. też: J. Wadowski, Projekt metody dialogicznej jako drogi spetnienia w THEOSIS, „Filozofia Dialogu” 2005, t. 3, s. 37-60 .

53 Por. np. J. Czerny, B. Krzyszpin, Wprowadzenie do cywilizacji XXI wieku, Bytom 2006. Książka ta w sposób bardzo wnikliwy i syntetyczny prezentuje dramatyzm sytuacji cywilizacji Zachodu. 
są przyczyny destrukcji siebie samego i swego otoczenia przez jednostki i społeczeństwa, niejednokrotnie wykształcone i rozwinięte? Sądzę, że główną przyczyną takiego stanu rzeczy jest wspomniana wyżej specjalizacja oraz związana z nią fragmentacja, która rzutuje na zredukowane postrzeganie człowieka zarówno w aspekcie strukturalnym, jak i procesualnym.

Fragmentacja ujęć obecna jest w całej kulturze, a ich rodowód to przerost swoistego minimalizmu, zawarty między innymi w pozytywizmie, behawioryzmie i pragmatyzmie. Konsekwencje tego procesu dotknęły również nauki humanistyczne, w tym filozofię ${ }^{54}$. Tymczasem wydaje się, że „królowa nauk" - pod wpływem presji metodologii nauk szczegółowych - dobrowolnie rezygnuje z przysługujących jej uprawnień ${ }^{55}$.

Zjawisko to zachodzi również $\mathrm{w}$ odniesieniu do kwestii rozumienia i dyskutowania o dobru i złu. Wielu polemik można by uniknąć i zmienić ich tok, gdyby większość dyskutujących zgodziła się, iż powszechność specjalizacji i dominacja badań empirycznych (których oczywiście nie należy negować) prowadzi do syndromu "pomieszania języków”, w związku z czym "rozchodzimy" się w różne strony świata, kierowani uprzedzeniami, poprzestając na zdobywaniu punktów, grantów itd. Waga i skala pytań egzystencjalnych zostaje rozmieniona na drobne zagadnienia lokujące się $\mathrm{w}$ sferze science correctness.

$\mathrm{W}$ jednym $\mathrm{z}$ artykułów na temat chorób cywilizacyjnych trafnie zdiagnozowano przyczyny chorób u osób dorosłych, wskazując na silną presję na sferę mentalną $\mathrm{w}$ epoce współczesnej56. Przewlekły stres wynikający z nieustającego wyścigu i konkurencji prowadzi najpierw do drobnych uszkodzeń i odchyleń czynnościowych w organizmie, które w perspektywie lat skutkują różnymi chorobami57. Autorzy tej publikacji stawiają tezę, iż znajdujemy się ciągle przed szczytem chorób cywilizacyjnych związanych z warunkami życia w tak zwanej „cywilizacji rozwiniętej”; konsekwencją większości tych chorób może być między innymi zatrzymanie się człowieka $\mathrm{w}$ rozwoju ${ }^{58}$. Jest charakterystyczne, że cywilizacja rozwija się w sferze kultury materialnej, natomiast $\mathrm{w}$ sferze kultury niematerialnej obserwujemy

\footnotetext{
${ }^{54}$ Daje się wszelako zauważyć pewną zdrową tendencję poszukiwania ujęć integralnych, chociażby w filozofii polskiej, m.in. w pracach takich autorów, jak: A.L. Zahariasz, M. Szulakiewicz, T. Kobierzycki, J. Mizińska, H. Romanowska-Łakomy, S. Symotiuk i in.

${ }^{55}$ Podczas X Zjazdu Filozoficznego w Poznaniu jeden z profesorów oświadczył, iż winę za swój kryzys i marginalizację ponosi sama filozofia, która wycofuje się w autentycznego angażowania po stronie określonych wartości.

${ }^{56}$ P. Koberda, U. Stodolska-Koberda, Rozwój psychiki u osób dorostych a etiologia chorób cywilizacyjnych, „Choroby Serca i Naczyń" 2008, t. 5, nr 1, s. 37-44.

57 Ibidem, s. 43

58 Ibidem.
} 
ewidentny regres ${ }^{59}$. Sądzę, że jedną z przyczyn tego zjawiska jest właśnie określony sposób rozumienia człowieka, traktowany zwykle jako oczywisty i jedyny możliwy. Można tu przypomnieć zdanie Abrahama Joshuy Heschela, iż „to, co określa czyjeś bycie ludzkim, to wizja, którą ten ktoś przyjmuje [...]. Wszelka próba, by wywieźć tę wizję z natury ludzkiej, powoduje jedynie wydobycie wizji, którą na początku w wizję wszczepiono" 60 . Rezultatem takiej wizji jest pogłębiająca się dehumanizacja człowieka oraz postępująca humanizacja zwierząt ${ }^{61}$.

Interpretacje bardziej integralne są marginalizowane; dotyczy to takich ujęć, jak np. Teoria Dezintegracji Pozytywnej (K. Dąbrowskiego), psychosynteza (R. Assagioli), personalizm chrześcijański (np. K. Wojtyła, E. Stein, D. von Hildebrand i in.), koncepcje Victora Frankla, eko-filozofia Henryka Skolimowskiego, transpersonalizm (S. Grof, K. Wilber), ujęcia Jeana Gebsera $\mathrm{i}$ in. Wszystkie te propozycje, mimo głębokich niekiedy różnic, ukazują człowieka jako istotę transcendującą siebie samą i społeczeństwo, zdolną do wielkich przedsięwzięć $w$ różnych dziedzinach, twórczo przezwyciężającą kryzysy itd. Owo pragnienie integralności i pełni, jako doświadczania głębszego wymiaru i sensu istnienia, przyczynia się jednak również do generowania teorii, które wydają się arbitralne. Przykładem jest teoria i system, jaki stworzył wspominany wcześniej Ken Wilber62. Według niektórych źródeł, jest on najczęściej tłumaczonym (na około trzydzieści języków) pisarzem akademickim i jednym z najważniejszych współczesnych filozofów ${ }^{63}$. W Polsce myśl Wilbera, w kontekście pedagogicznym, została opracowana przez Marzannę Kielar. W 2014 roku odbyła się w Bukareszcie Pierwsza Integralna Europejska Konferencja. Jakkolwiek postawa ignorowania dokonań Wilbera i jego Integral Institute nie jest słuszna, to wydaje się, iż jeśli redukcjonizm popełnia błąd wyjaśniania tego, co wyższe, przez to, co niż-

59 Wspomniany redukcjonizm jest tak powszechny, że ogólnie obowiązująca terminologia nikogo już nie dziwi. Gdy mówi się np. o „rozwoju”, ma się zwykle na myśli ekspansję o charakterze ilościowym. Kryterium ilości, ze względu na dominację ekonomizmu, stało się centralne niemal w każdej sferze życia, opierając się na kolejnym fałszywym przekonaniu, iż ilość musi przechodzić w jakość.

${ }^{60}$ A.J. Heschel, Kim jest człowiek?, tłum. K. Wojtkowska, Łódź 2014, s. 33

${ }^{61} \mathrm{~J}$. Śledzianowski, Dehumanizacja człowieka $i$ humanizacja zwierząt, Kielce 2014. Można oczywiście nie zgadzać się katolickim podejściem zaprezentowanym w wymienionej pozycji jednak wydaje się, że wiele spostrzeżeń i wniosków tam zawartych jest jak najbardziej słusznych.

62 Por. np. K. Wilber, Eksplozja świadomości, tłum. K. Przechrzta, E. Kluz, Kraków 1997; idem, Krótka historia wszystkiego, tłum. H. Smagacz, Warszawa 1999; idem, Psychologia integralna. Świadomość, duch, psychologia, terapia, tłum. H. Smagacz, Warszawa 2000. Wilber doczekał się edycji dzieł wszystkich jeszcze za swojego życia.

${ }^{63}$ https://integrallife.com/contributors/ken-wilber (dostęp: 10.03.2015 r.). 
sze, to proponowana przez Wilbera teoria wszystkiego jest psychologiczną wersją filozofii wieczystej Aldousa Huxleya, której oczywiście nie można odmówić oryginalności i siły oddziaływania, a jej sukces świadczy o znużeniu redukcjonistycznym podejściem oraz poszukiwaniu rozwiązań alternatywnych $w$ stosunku do konsumpcyjnego stylu życia i myślenia. Teoria Wilbera $^{64}$ wychodzi naprzeciw oczekiwaniom społeczeństw zmęczonych materializmem i redukcjonizmem ontologicznym, za którym idzie dominacja ekonomizmu i praktycznego materializmu.

Nawet jeśli można poddać krytyce szczególną arbitralność w myśleniu Wilbera, to wydaje się, że w sytuacji narastającego kryzysu i potęgującej się dezorientacji, konieczne jest poszukiwanie modeli integralnych, które z różnymi zastrzeżeniami - mogą się stać podstawą wspólnych dyskusji. Jednak gdy każdy z dyskutantów wychodzi z odmiennego "stanowiska” w rozumieniu człowieka, dyskusja na temat tego, co dobre i złe, wydaje się syndromem "pomieszania języków”. W tym kontekście rozmowa taka staje się wyrazem subiektywizmu i niczym więcej. Nie poszukujemy już punktów wspólnych, a usiłujemy tylko przeforsować własne, „jedynie słuszne” rozumienie. Gdyby zrozumienie i prawda była postrzegana jako określone dobro wspólne, o które należy się troszczyć i starać, wtedy być może zakiełkowałby dialog i można by było zacząć epokę spotkania, które jest jednym z warunków przetrwania cywilizacji.

Miarą ludzkiego życia nie jest tylko „sukces”, który może osiągnąć niewielu, ale radość z istnienia tu i teraz, satysfakcja z wykonywanej aktualnie pracy, poczucie wewnętrznego pokoju i odkrywanie perspektyw w obszarze duchowości (niekoniecznie związanej z jakąś religią). Inaczej mówiąc, miarą jakości życia jest udział w wartościach prawdy, dobra i piękna, w sposób wieloaspektowy, poprzez otwartość na drugiego, łączność bądź jedność $\mathrm{z}$ tak lub inaczej rozumianą Transcendencją i świadomy udział w kulturze, szczególnie niematerialnej. Odkrycie wewnętrznej harmonii i siły, zdolność wybaczania, radość istnienia są "sukcesami”, jakich nie można osiągnąć przez społeczne formy uznania. Filozofia, rozumiana również integralnie jako „miłość mądrości”, ma tutaj do spełnienia niezwykle ważną rolę.

Obserwując pojawiające się trendy czy ideologie (np. transhumanizm), można prognozować, że w obliczu systemowego kryzysu cywilizacji opartej na redukcjonistycznych przesłankach, propozycje integralne, zarówno te religijne, jak i areligijne, będą jednym z symptomów nadchodzącej epoki oraz renesansu filozofii, który - jak sądzę - nastąpi.

64 Streszczenie podstawowych zrębów filozofii Wilbera Czytelnik odnajdzie tu: http:// www.kheper.net/topics/Wilber/Wilber_I.html (dostęp: 13.03.2015 r.). 
Parafrazując Hegla, można powiedzieć, że człowiek jest całością. Człowieka nie można rozpatrywać w oderwaniu od kategorii całości65. Człowiek, właśnie jako całość i jedność, określony jest przez różnorakie transcendencje. Jest on zdolny do przekroczenia własnych ograniczeń, cielesności, determinant środowiskowych, społecznych i in. Współczesne badania nieustannie wykazują szeroką gamę determinantów ludzkiej egzystencji, aczkolwiek można by napisać całą książkę o wolności ludzkiej i działaniu polegającym na autodeterminacji i samotranscendencji. Inaczej mówiąc, mamy tutaj do czynienia z pewną paradoksalnością samego człowieka, która wynika prawdopodobnie $\mathrm{z}$ jego plastyczności, podatności na ewolucję i nawet bardzo głębokie przemiany.

Integralne rozumienie osoby ludzkiej i jej rozwoju jest warunkiem niezbędnym do podjęcia wszechstronnej dyskusji na temat dobra i zła. W takiej sytuacji również te kategorie muszą być rozumiane w sposób w miarę pełny, ponieważ istnieje niebezpieczeństwo "stwarzania” sobie własnego przedmiotu badań przez redukcjonistyczne ujmowanie dobra, a w konsekwencji również zła. Tu, jak sądzę, leży źródło nieporozumień i jałowych dyskusji „co można?", „co powinno się?" lub „w jaki sposób?" Integralność ta musi być rozumiana zarówno horyzontalnie, jak i wertykalnie. W obydwu tych wymiarach ujawnia się głęboko relacyjny charakter osoby, co uwidacznia się w samym znaczeniu pojęcia osoby jako prosopon. Podstawowe "redukcje” człowieka to socjologizm oraz indywidualizm. Tymczasem człowiek powinien być rozpatrywany w kategoriach osobowo-wspólnotowych ${ }^{66}$.

Człowiek jest istotą wielopoziomową, na co wskazuje Wilber. Większość ludzi w czasach propagandy egzystencji jednowymiarowej jako oczywisty traktuje jeden z tych wymiarów, któremu poświęca najwięcej uwagi. W wersji „oficjalnej” człowieka sprowadzono do poziomu animal rationale ${ }^{67}$. Sądzę jednak, że człowiek ani nie jest zdecydowanie animal, ani też nie jest do końca rationale. Inaczej rzecz ujmując, każde $\mathrm{z}$ tych ujęć coś mówi nam o człowieku, o niektórych, być może ważnych, jego ekspresjach, jednak nie wyczerpuje bogactwa bycia człowiekiem.

Przede wszystkim, w świecie redukcjonizmu i technokracji coraz bardziej widoczne jest dążenie do integralnej duchowości, w sferze której powstają sądy na temat dobra i zła, przyjmowane jako wiążące dla jednostki

65 Por. L. Miodoński, Całość jako paradygmat rozumienia świata w myśli niemieckiej przełomu romantycznego. Analiza wybranych problemów, Wrocław 2001.

${ }^{66}$ D. von Hildebrand, Metafizyka wspólnoty, tłum. J. Zychowicz, Kraków 2012.

67 Przyjmowana jako oczywista koncepcja człowieka stała się podłożem prawa, sposobu funkcjonowania różnorodnych instytucji i życia publicznego. Jeśli jednak myślenie o człowieku bazuje na redukcjonizmie, to negatywne efekty widoczne są bardzo szybko. 
lub społeczności ${ }^{68}$. Przyjmowanie stanowisk i wdrażanie w życie określonych zachowań wynika z faktu, który z „poziomów” funkcjonowania i działania człowieka przyjmiemy jako zobowiązujący i wiarygodny. "Człowiek to jestestwo religijne, moralne, artystyczne, polityczne czy też społeczne, ale sprowadzanie jestestwa ludzkiego do któregokolwiek z tych określeń prowadzi do zawężenia jego pojmowania"69. Zauważyli to również inni filozofowie, jak np. Józef Tischner, Chantal Delsol czy Marek Szulakiewicz. Ten ostatni słusznie zauważa, że postawione jeszcze przez Kanta słynne pytanie „kim jest człowiek?” ograniczono niemal wyłącznie do aspektu poznawczego. W ten sposób możemy wykryć niektóre źródła współczesnych redukcjonistycznych ujęć, które bogactwo bycia człowiekiem sprowadzają do jednego z wymienionych jego aspektów. Sam Szulakiewicz wskazuje na trzy wymiary człowieka: fizyczny, racjonalny (świadomość) i duchowy ${ }^{70}$. Wszelkie dyskusje na temat dobra i zła wychodzą zwykle tylko z jednowymiarowej wizji człowieka, stąd niejednoznaczność, a także brak zgody na jeden typ ujęcia. Ta niejednoznaczność z kolei powoduje, że relatywizuje się wszelką etykę. Jeśli przyjmie się „zwierzęcą" wizję człowieka, na którą poszukuje się dowodów naukowych, to w tym momencie samo dobro będzie się postrzegać jako element strategii biologicznego przetrwania. Natomiast Szulakiewicz twierdzi, za Tomaszem Mertonem, że podstawowym kluczem do odkrycia prawdy i dobra jest miłość, nie zaś czysto intelektualistyczne poznanie ${ }^{71}$. Oczywiście, jeśli mówimy o miłości, musimy zerwać z jej sentymentalną i jednowymiarową interpretacją; miłość jako fenomen jawi się człowiekowi w różnorodny sposób, jak to opisał np. Hildebrand ${ }^{72}$. Psychologia, również jako nauka empiryczna, zdaje się potwierdzać, iż człowiek funkcjonujący wyłącznie na poziomie intelektualnym jest osobą zreduko-

${ }^{68}$ Zob. Nowa duchowość w społeczeństwach monokulturowych i pluralistycznych, red. K. Leszczyńska, Z. Pasek, Kraków 2008.

${ }^{69}$ A.L. Zachariasz, op. cit., s. 31. Konsekwencje określonych zawężeń sposobu rozumienia człowieka widoczne są w kwestiach konstruowania obowiązującego prawa, które w konsekwencji, zamiast wspomagać społeczeństwo w rozwoju osobowym, zaciska tylko niewidzialną pętlę kontroli i manipulacji.

${ }^{70}$ M. Szulakiewicz, O czlowieku..., op. cit., s. 56. Oczywiście, jak niemal do każdego podziału władz, można mieć i tu zastrzeżenia, pytając np. o miejsce emocji i uczuć czy woli. Szczególnie cenne wydaje się jednak wskazanie na wymiar duchowy, który przekracza świadomość rozumianą jako racjonalność.

71 Ibidem, s. 57. Integralnie rozumiana miłość nie jest tylko jakąś formą uczucia, jednak można przypuszczać, że wielu filozofów w najlepszym razie zignoruje takie podejście, stojąc na stanowiskach intelektualistycznych, uważanych za jedynie dopuszczalne.

72 Zob. D. von Hildebrand, op. cit., szczególnie rozdział 5 w częsci I. 
waną, pozbawioną potencjalnej ludzkiej pełni ${ }^{73}$. Pełnia ta możliwa jest na drodze heroicznej, o której tak wnikliwie - porównując świętość i mądrość pisze Szulakiewicz, przekonując, że mogą one być bardzo blisko siebie ${ }^{74}$. Natomiast w wyniku wdrażania redukcjonistycznych programów, „wielu ludzi czuje się spełnionymi, zrealizowanymi i oczekuje już tylko «siódmego dnia wypoczynku». Zamiast drogi dojrzałości i przekraczania siebie samego, chodzi się już «na skróty» we wszystkich dziedzinach życia, nie wyłączając uniwersytetów"75.

Budowanie integralnej antropologii nie może mieć charakteru ideologicznego. Antropologia taka powinna inspirować się różnorodnymi stanowiskami i systemami. Niewątpliwie w naszej kulturze wiele do powiedzenia ma filozofia chrześcijańska, stojąca $\mathrm{w}$ opozycji do wielu współczesnych trendów i mająca swoje różnorodne oraz bogate propozycje ${ }^{76}$. Aby antropologia taka mogła faktycznie zostać „królową filozofii” - zgodnie z postulatem Kanta - wszystkie pytania powinny sprowadzić się w niej się do jednego - pytania o człowieka.

Nie jest możliwa jakakolwiek ucieczka od wolności czy odpowiedzialności ${ }^{77}$. Dlatego też idea pluralizmu może prowadzić do sytuacji, która uprawomocnia lenistwo duchowe społeczeństwa, stwarzając iluzję, że żadna hierarchia wartości nie jest prawomocna ${ }^{78}$. W takich okolicznościach, we mgle "płynności”, można uzasadnić każde postępowanie i każde nadużycie. Syndrom państwa policyjnego jest równie niebezpieczny jak syndrom społeczeństwa, które toleruje każde zachowanie w imię źle pojętej wolności. Nie jest możliwe (chyba że w sferze deklaracji) wprowadzenie relatywizmu aksjologicznego, zarówno psychologicznie, jak i społecznie. Bogactwo i różnorodność kultur nie musi kłócić się z absolutystycznym ujęciem wartości79. Absolutyzm natomiast, dodajmy, nie musi oznaczać systemu braku tolerancji i nienawiści. Oznaczać on może poszukiwanie tego, co wspólne wszystkim ludziom na planecie, a co jest wręcz imperatywem epoki, wywołanym w dużej mierze przez technikę (szczególnie w sferze logistyki i komunikacji). Odnalezienie takiej uniwersalistycznej perspektywy jest być może wa-

${ }_{73}$ Por. np. S. Baron-Cohen, Teoria zła. O empatii i genezie okrucieństwa, tłum. A. Nowak, Sopot 2014 .

${ }^{74}$ M. Szulakiewicz, O człowieku..., op. cit., s. 67.

75 Ibidem, s. 33

76 Ponieważ myśl ta jest dość dokładnie zaprezentowana i opisana w literaturze, autor podjął się w niniejszej wypowiedzi nieco innej drogi, aczkolwiek postulat ujęcia integralnego filozofia realizuje w sposób optymalny np. u K. Wojtyły, E. Stein czy D. von Hildebranda.

77 M. Szulakiewicz, O człowieku..., s. 111.

78 Ibidem s. 116.

${ }^{79}$ Ibidem, s. 143. 
runkiem naszego przetrwania ${ }^{80}$. Przede wszystkim dzięki temu, że sama filozofia jest właśnie fenomenem uniwersalnym ${ }^{81}$.

Należy podkreślić, że tylko antropologia filozoficzna może pracować nad integralną i uniwersalną koncepcją człowieka. Powinna też tworzyć teoretyczną bazę dla wszelkich innych badań, pozwalając budować między innymi systemy etyczne umożliwiające odnalezienie szansy moralnego porozumienia i konsensusu w wymiarze globalnym.

Dopiero w takim kontekście, w relacji z Innym oraz z Przyrodą i różnie rozumianą Transcendencją, można mówić o kwestii dobra lub zła. Bardzo prawdopodobne, że jednym ze źródeł zła jest lęk, poczucie samotności, cierpienie oraz oczywiście niewiedza, czy raczej nieświadomość, własnej słabości i ograniczeń. Inaczej mówiąc, iluzje, złudzenia związane są z przyjmowaniem zredukowanej wizji człowieka, którą bierze się za całą prawdę.

\section{Between Reductionism and Quest for Fullness. Integral Understanding of a Man as a Basis for an Ethical Discussion}

\section{Summary}

A late modernity is an age of the extremes. They are marking: reductionism (1), technologizing (2) and massification (3). Consequences of reductionism in understanding the man are negative for him and for surroundings. On such an anthropological theory, assuming determined metaphysics, based a majority of researches in the problem of the good and evil. However in the humanistic sciences integral theories are more often popular, what is probably results from unconscious seeking the plenitude. In order to undertake versatile presentations of the good and evil, anthropological concepts diverse and using up, though not arbitrarily are necessary.

80 Ibidem, s. 157. 2013.

81 Ibidem, s. 182. Por. też: S. Rainko, Powotanie filozofii. Esej metafilozoficzny, Warszawa 